\title{
Introduction to the Research Handbook on Child Soldiers
}

\author{
Mark A. Drumbl and Jastine C. Barrett*
}

I was skinny, weakly, slight; you were strong, tall, broad. Franz Kafka, Letter to Father (1919) ${ }^{1}$

Throughout history, armed conflict has ensnared children. On occasion such children have been lauded as heroes or, at least, praised for their martial courage in the darkness of desperate times. Increasingly, however, the involvement of children in armed conflict is no longer seen as unbecoming or an anguished last stand but, instead, as flatly impermissible with the affected children projected as afflicted victims. Global consciousness has shifted. The drift of international human rights law, international criminal law and international humanitarian law both reflects and hardens this shift. The relationship of the child with armed conflict has migrated from one informed by ethics, needs and morality to one regulated by law, rules and public policy. The international community is progressively moving towards a position where the conscription, enlistment or use in hostilities of persons under the age of 18 - in particular by armed groups but also increasingly by armed forces - is seen as unlawful.

Many activist and humanitarian groups commit to the cause of ending child soldiering. UNICEF and other United Nations (UN) organs have deeply invested themselves in this mission as well. In 1996, pursuant to a UN General Assembly resolution, Graça Machel of Mozambique submitted a ground-breaking report entitled Impact of Armed Conflict on Children (widely known as the Machel Report). ${ }^{2}$ The Machel Report firmly put children and violent conflict on the international agenda and has had considerable social constructivist influence. In light of one of its recommendations, for example, the Office of the Special Representative on Children and Armed Conflict was established within the UN system. The UN Security Council, generally fractured, has unified to issue 12 resolutions over the past two decades on children in armed conflict. ${ }^{3}$ The focus of law- and policymakers has further expanded to address the place of children in terrorist groups and to interrogate how counter-terrorist strategies and initiatives should approach such children.

Popular culture, along with the international legal imagination, generates a rather simplified image of the child soldier: stereotypically, a poor, abducted, prepubescent African boy, in dilapidated sandals, barely able to hold his AK-47. This essentialized image nonetheless belies the far greater complexity of where children become implicated

Some parts of this Introduction draw from and re-work sections of Drumbl 2019.

Kafka 2018: 15.

Machel 1996.

These are: UN Security Council Resolutions 1261 (1999), 1314 (2000), 1379 (2001), 1460 (2003), 1539 (2004), 1612 (2005), 1882 (2009), 1998 (2011), 2068 (2012), 2143 (2014), 2225 (2015) and 2427 (2018). 
in armed conflict and when (as a matter of age) children become soldiers, as well as how and why they become involved. Readers may be surprised to learn the following facts: many children soldier outside Africa (and increasingly so); many children fulfil functions that do not involve carrying weapons; most child soldiers worldwide are adolescents rather than young children; the most common path to militarized life is not abduction and kidnapping but for children to come forward with varying degrees of volition and become enlisted; and children may face greater threats from their 'side' than from the 'enemy', including sexual slavery and forced marriage.

In assembling contributions for this Research Handbook on Child Soldiers, we as editors have sought to imbue the project with a global scope, disciplinary diversity and innovative angles. We hope to lift the reader beyond customary places and reflexive spaces and increasingly ill-fitting conventionalities.

Although it is estimated that 40 per cent of child soldiers worldwide are girls, the invisibility of the girl soldier from the imagery of child soldiering - and hence from rehabilitative and re-integrative programming - remains deeply disappointing. Many research studies on child soldiers that do approach gender do so as a silo, that is, as a separate dimension. This Research Handbook proceeds differently. It holistically incorporates gender throughout the entire text as a core constitutive element of violence, reintegration, identity and transition. In this vein, as Valerie Oosterveld has compellingly noted, the goal is to 'surface' the experiences of girls, and to do so integrally and not in a separate side-bar. ${ }^{4}$ This means 'surfacing' the multiple ways in which armed conflict affects girls (and how girls affect armed conflict) - as victims, bystanders, side-standers, perpetrators and leaders - with a view towards promoting cultures of juvenile rights and gender equality. This Research Handbook, moreover, also aims to 'surface' the experiences of boys, including as perpetrators but also as victims of wretched sexual violence, thereby presenting boys in the variety of composite roles they may play in armed conflict.

The historicity of child soldiers - of drummer boys and Spartans and Jeanne d'Arc also means that child soldiering has a deep intertemporal dimension to it. This Research Handbook seeks to address this as well, by including contributions that present the then as well as the now. The experiences of the child soldier are dual in nature: the life of the soldier as lived in the body and soul of the child. These experiences are intertwined oxymoronically perhaps - but each is fragile in its own way. The soldiering aspect erupts with threats, chaos, brutality, hunger, opportunity, loss and victory. Childhood, too, presents as a moment of contingency. As Franz Kafka remembers, childhood implicitly is a state of vulnerability: the inexorability of smallness in contrast to the unavoidability of the girth of adults, adults who take up all the room, who suck up all the oxygen. Kafka, assuredly, was no child soldier. Growing up as he did in Prague, when he did at the turn of the twentieth century, Kafka did come of age amid periods of distress and violence: wars, the imposition and dissolution of empire, the reality of his Jewishness in a world besotted with anti-Semitism. But, no, Kafka didn't soldier. In his Letter to Father he touches nonetheless on childhood. And his childhood was a taut one. It was one of anxiety. Along with masterpiece novels, Kafka wrote over 1,500 letters in the 41 years of his life. He loved writing letters. He was impatient to receive them from others. Letter to

\footnotetext{
4 Oosterveld in this volume.
} 
Father, which he penned at the age of 36, is his longest. It filled over 100 sides of written manuscript pages. Yet Kafka never sent it. Instead, it was published well after his death and after the death - several years later - of his father, to whom the letter was addressed. Hermann Kafka, the father, was by all means a towering - if not omniscient - figure (certainly to Franz). Starting from nothing in a village in Bohemia, Hermann began as a haberdasher and then grew into a commercially successful shopkeeper. His shop, located in the oldest part of Prague's gorgeous Old Town, was a central fixture of Franz's life. Franz's memories, however, were sour. The father was strict and demanding. He was tough. Franz, the eldest and only surviving boy, was not. Franz struggled - as all children do, though Franz struggled a great deal - to be himself, to become himself, to move out of the shadows of the adult, to speak and not only be spoken to. Kafka's letter, then, is as much about him as it is about all children; it is as much about his recollections as it is about all adults when they replay their childhood(s); it is about agency and authority, love and suffocation, abuse and growth, legacies and reincarnations.

One of the goals of this Research Handbook is - tracing Kafka's words that opened this introduction - to make the child less slight, and the adult less broad. Doing so may blunt the might of gerontocracy and lay the groundwork for more humanistic relations among ages and a richer culture of intergenerational equity. Such a recalibration seems all the more necessary in a world in which the future feels so precarious due to the conduct of the adults of today; with legacies of climate change, for example, among other destructive imperia foisted upon the young as their inheritance. This, too, is a goal of this Research Handbook: to think twice about the forces, and the orthodoxies, that conspire to crowd out the child (and the future) with the needs of the adult (and today). We hope to make the child a greater part of the present.

While most of the contributors to this Research Handbook are not lawyers - and one of the sparks catalysing this volume is to bridge disciplinary and professional divides international law, best practices and transnational policies constitute a central touchstone of the discussion. In order to welcome readers to this thicket and offer some common ground, this introduction sets forth a snapshot of how law, policy and best practices attribute responsibility for child soldiering and approach the allocation of responsibility to child soldiers. This introduction continues with an overview of the contents of this Research Handbook. It ends by gesturing towards roads not taken, gaps that arise and journeys that still might be initiated. First, however, three quick successive interventions: first on terminology, then on globality and last on an emancipatory epistemology.

\section{A NOTE ON TERMINOLOGY}

The 2007 Paris Commitments and Paris Principles, two connected non-binding instruments, cultivated different language than 'child soldier', that is, 'a child associated with an armed force or armed group'. ${ }^{5}$ The Paris Principles did so to underscore the variety

5 These Principles and Commitments, endorsed by 108 states, build upon the 1997 Cape Town Principles and Best Practices on the Recruitment of Children into the Armed Forces and on Demobilization and Social Reintegration of Child Soldiers in Africa. 


\section{Research handbook on child soldiers}

of roles that children may play in armed conflict, namely as more than 'soldiering', and also to recognize the range of actors that may recruit or use them. ${ }^{6}$ According to the Paris Principles:

A child associated with an armed force or armed group' refers to any person below 18 years of age who is or who has been recruited or used by an armed force or armed group in any capacity, including but not limited to children, boys, and girls used as fighters, cooks, porters, messengers, spies or for sexual purposes. It does not only refer to a child who is taking or has taken a direct part in hostilities.

The phrase 'children associated with armed forces and armed groups' is indeed tonguetying, so UN agencies and international activists have turned to the acronym CAAFAG instead. Yet this, too, is phonetically awkward. It is noteworthy, in a cyclical sense, that the most recent set of political commitments on the topic of children affected by armed conflict, fostered by the Canadian government in 2017, are expressly titled the Vancouver Principles on Peacekeeping and the Prevention of the Recruitment and Use of Child Soldiers. ${ }^{7}$ The old phrase, once disfavoured yet still evocative, seems to be regaining some ground.

So the bottom line is this: in this Research Handbook we tend to deploy the term 'child soldier' but always understand its meaning to reflect the definition as provided by the Paris Principles.

The lines between the delinquent, criminal, terrorist, extremist and soldier may be gauzy and may be appropriated for ulterior purposes. Language matters. For example: how to narratively imagine 17-year-old Burhan Hassan, a straight-A high schooler who disappeared from Minnesota in 2008 for Somalia to train for recruitment into al-Shabaab only to be killed half a year later? ${ }^{8}$ Was Burhan a child terrorist, a child gang member, a child thug, or a child soldier?' The 'law on child soldiers' differentiates armed groups (and armed forces) from other groups - thugs, gangs, criminal organizations - and bestows legal personality only on armed groups (and armed forces), meaning that the protective embrace, for example of the Paris Principles, only hugs children associated with groups determined to have the capacity to engage in armed conflict. States may resist the appellation of child 'soldier' to children associated with terrorist groups, citing security concerns. This jeopardizes the rights of those children and triggers potential abuses. ${ }^{10}$

This Research Handbook adopts a broad lens and therefore also discusses children not associated with an armed force or armed group whatsoever but otherwise affected by conflict-related violence, as well as children associated with groups discursively character-

6 An armed force refers to the national militaries of a state, whereas an armed group refers to a fighting force that is separate from a state, for example, rebel groups.

7 As of 12 October 2018, 68 states have endorsed the Vancouver Principles. These Principles strive to prevent child recruitment in the context of peacekeeping operations and mandate peacekeepers to receive clear guidance regarding children associated with armed forces or armed groups.

8 Many thanks to Hawa Allen for sharing her thoughts on Burhan Hassan; see also Bloom in this volume.

9 For discussion of comparable tensions within Colombia, see Jiménez in this volume.

10 For discussion of Omar Khadr and other children, see Rosen in this volume and CaseyMaslen in this volume. 
ized as 'terrorist' or 'extremist' rather than 'armed'. Children in 'criminal syndicates' are also present throughout these pages. Recruitment patterns into such syndicates may bear parallels to those operative in the context of 'armed' groups.

The term 'child soldier' may alternately be deployed to signify urgency, exigency and crisis. One recent news report about criminal activity in the Cape Flats areas of Cape Town, South Africa, begins with a mother speaking of her 15-year-old as referring to himself 'as a soldier for the local gang'. ${ }^{11}$ A founder of a civil society organization adds: 'Commonly it is understood a child soldier is a youngster with a gun in war and many of us deny child soldiers exist in the Western Cape. But the meaning of child soldier in our societies is very simple and we cannot deny there are youngsters with guns in Cape Town.' ${ }^{12}$ A South African academic pleads:

A child soldier in the Ugandan context has primarily been associated with groups that are directly working to overthrow established state institutions. However, in other contexts, children may also become participants trapped in the violence of armed groups in their own communities, and they are still children at war and we must go beyond conventional notions of who the child soldiers are. ${ }^{13}$

Regardless of nomenclature, the point remains: creative thinking about reintegration and prevention in the context of child soldiering has the potential to catalyse much wider reflections upon the general interactions between children and criminal justice systems.

A final point on terminology: the vast majority of children associated with armed forces or armed groups worldwide are 16- and 17-year-olds who may consider themselves less as children and more as young adults. ${ }^{14}$ Obviously there are horrific exceptions of very young children who become militarized against their will, including in terrorist groups, but these remain exceptions. It is important to keep this in mind - both when considering how children join armed groups, but also how they leave armed groups: infantilizing juveniles may not only underestimate their agency but can also have a counterproductive impact on efforts taken to reintegrate them.

\section{A NOTE ON GLOBALITY}

Child soldiering is a global phenomenon that is much more nuanced than might appear at first blush. It is generically estimated that, in recent decades, between 250,000 and 300,000 children worldwide are associated with armed forces or armed groups. Some observers suggest that these figures, however potentially accurate at one point, have since diminished in terms of quantifying the numbers of children currently serving in armed forces or armed groups. ${ }^{15}$ We believe these observers make a good point. Yet children who have once served become former child soldiers who seek to reintegrate into society, and

Lepule 2018.

Ibid.

Ibid.

14 See generally Drumbl 2012.

15 See Talbert and Wolfendale 2018 ('At least 100,000 people under the age of 18 serve in various capacities in armed groups around the world'). 


\section{Research handbook on child soldiers}

remain a crucial component of studies aimed at youth, militarization and transitional justice. Former child soldiers constitute a central concern of this Research Handbook.

What is more, sadly, conflicts wax and wane and, concomitantly, so do the numbers of children affected by armed conflict and the locations where child soldiering occurs. Child soldiers - as with former child soldiers - exist in each of the world's regions. The 2018 Annual Report of the UN Secretary-General on Children and Armed Conflict noted an increase in the number of children affected by armed conflict and the severity of the grave violations in question. Specific mention was made of recruitment and use in the Central African Republic, Somalia, Democratic Republic of the Congo, South Sudan, Syria and Yemen. ${ }^{16}$ Reporting in 2018, the Office of the Special Representative of the Secretary-General on Children and Armed Conflict found that progress has been made in terms of releasing children from armed groups in Colombia, the Philippines, Sudan and Mali, ${ }^{17}$ but also expressed concerns about abduction and recruitment in Somalia, Nigeria, Libya, Cameroon, Niger, Iraq and Syria. ${ }^{18}$ In 2016, it was found that armed groups accounted for 54 out of 63 parties listed for grave violations against children. ${ }^{19}$ Armed groups, however relevant, still only form part of the picture. In 2018, the Special Representative noted that:

More than 50 per cent of armed groups included in the annexes to the annual report of the Secretary-General on children and armed conflict for the recruitment and use of children are active in countries where government forces are also listed, illustrating that the actions of armed groups are influenced by the conduct of government forces. ${ }^{20}$

Myanmar's government, for example, has recruited children through harsh methods. Estimates are that one-quarter of its national armed forces (the Tatmadaw) consists of persons under the age of 18 . The Tatmadaw are currently implicated in mass violence perpetrated against Rohingya Muslims.

Persons under the age of 18 , moreover, volunteer to join armed forces under special conditions and protections. In the years 2013 to 2015, for example, the United States recruited 49,035 (35,581 males and 13,454 females) 17-year-olds (about 6 per cent of total voluntary enlistments). ${ }^{21}$ The United Kingdom is another example of armed forces in which minors are voluntarily enlisted. ${ }^{22}$ So, too, is Canada (at the age of 16). France also allows for the voluntary recruitment of under $18 \mathrm{~s}$ into its armed forces - non-nationals can also be recruited at 17 in the Foreign Legion. ${ }^{23}$ In 2017, the number of minors in the German army (the Bundeswehr) rose to 2,128 - the highest recorded level - from a previous high-water mark in 2016 of 1,907 (in 2011, the year that mandatory military

16 UN Secretary-General 2018: [6]. See also [7] ('In Nigeria, Boko Haram continued to force civilians, including children, to perpetrate suicide attacks, which led to over half of all the verified child casualties in the country').

17 UN SRSG for Children and Armed Conflict 2018a.

18 UN SRSG for Children and Armed Conflict 2018b.

19 UN SRSG for Children and Armed Conflict 2016: 3.

20 UN SRSG for Children and Armed Conflict 2018a: [28].

21 US Department of Defense 2016.

22 See Crilley in this volume.

23 See Hanson and Molima in this volume. 
service for males ended, there were only 689$).{ }^{24}$ Of the 2,128 recruits in 2017,448 were women - an eightfold increase since 2011 (when there were 57 female soldiers under 18). In 2017, persons under the age of 18 accounted for 9 per cent of the Bundeswehr's new recruits. ${ }^{25}$ In 2014, the UN Committee on the Rights of the Child told Germany that it should raise its recruitment age. The Bundeswehr has nonetheless defended its recruitment of 17-year-olds and, like its counterpart in the UK, has turned to online video campaigns in its recruitment drive. In 2017, the German army spent about 35 million euros on recruitment, a figure that one news report identified as double the level of spending in $2011 .{ }^{26}$ One recent German juvenile recruit, Marlon, had watched a series of YouTube videos before signing up. As for his mother's consent: well, 'she was happy to give it and is now pleased her once-messy son has become more organized' ${ }^{27}$

National armed forces and police constabularies, moreover, come into contact with child soldiers who may fight for the 'other side'. How to act in such invidious circumstances? Throughout 2017, authorities in Iraq, Kurdistan and Syria routinely detained and abused children suspected of association with ISIS. The UN Office of the Special Representative specifically criticizes the detention by states of children for alleged association with such armed groups, and, also, the use by these armed groups of children as human bombs.

\section{AND A FINAL PREFATORY NOTE ON AN EMANCIPATORY EPISTEMOLOGY}

From where do 'we' know what 'we' know about child soldiers? In terms of the development of the law, best practices and policy, two informational sources have dominated: child psychology and trauma studies, on the one hand, and reports published by transnational pressure groups, NGOs, activists and UN agencies, on the other.

Other disciplines and their literatures have not resonated as earnestly with the international legal imagination. Thus, contributions from other fields remain untapped, which is unfortunate since many hail from the Global South. Examples of undervalued contributions include ethnographic participant observation, anthropological studies, qualitative research, survey data and feminist theory. Another is adolescent developmental neurobiology, which focuses on the social category of adolescents as distinct from young children. These literatures articulate a more dynamic account of child soldiers as interacting with, instead of overwhelmed by, their environments. These literatures also tend to align children, adolescents, youth and adults along a broader continuum that is less rigidly stratified by chronological age demarcations and bright-line distinctions tethered to the age of 18 (or any age). This Research Handbook, whilst it does not contain contributions from all of these fields, does seek to look beyond the usual disciplinary suspects and engages with multifarious methodological approaches in an attempt to broaden the conversation.

\footnotetext{
The Local 2018.

Alkousaa 2018

Ibid.

Ibid.
} 


\section{Research handbook on child soldiers}

There are three main ways in which individuals under the age of 18 become associated with armed forces or armed groups: (1) they are abducted or conscripted through force or serious threats; (2) they present themselves, whether independently or through recruitment programmes and become enlisted/enrolled; or (3) they are born into forces or groups. It is not always easy to demarcate the first two paths but they are distinguishable and, moreover, should be distinguished. The third path, birth into armed forces or groups, is the most uncommon and also among the most understudied. As editors, we are therefore delighted to be able to include in this Research Handbook a cutting-edge chapter by Myriam Denov of interview data from such children, born of war-time rape, in northern Uganda's Lord's Resistance Army.

Most child soldiers are neither abducted nor forcibly recruited. ${ }^{28}$ The international legal imagination, nevertheless, heavily emphasizes this path to militarization. Although helping to expose this horrific reality, this emphasis also leads to the under-theorization and under-exploration of youth volunteerism. Significant numbers of children join armed forces or armed groups in the absence of evident coercion and, in fact, exercise some - and at times considerable - initiative and enterprise in this regard. The picture is more far more complex than the international legal imagination acknowledges. To be sure, cases arise where determinations of volunteerism would be specious. ${ }^{29}$ Adults may deceive children and trick them into joining. Children may be offered up by family and community members in exchange for money or protection. Children may rashly present themselves for service because of excessive impulsivity. That said, many children, notably older adolescents, come forward intentionally to join armed forces or groups. Assuredly, they are influenced by environmental factors and fierce situational constraints: poverty, insecurity, lack of education, socialization into violence and broken families. We believe it useful to characterize the relationships of children with these factors as ones of push and pull in which children navigate circumscribed spaces. In joining armed forces or groups, children may simply - as best they can in tough circumstances - be negotiating paths of economic advancement, seeking inclusion in occupational networks, and pursuing political or ideological reform. Although assertions of volunteer service made by child soldiers should not be immune from rigorous interrogation, we believe it is wrong summarily to dismiss them. Young people may understand volunteerism within the context of their lives and apply it fairly to themselves.

One theme that weaves throughout this Research Handbook is that of recognizing that children's rights approaches oscillate between the protective impulse (children are vulnerable and need to be shielded) and the emancipatory impulse (children have evolving capacities and need to be supported, recognized and encouraged as societal participants). While the emancipatory approach fills many spaces associated with political participation (e.g. to lower the voting age, to permit autonomy in matters of reproductive rights and religious freedoms), the protective impulse tends to fill advocacy spaces regarding the desirability of military life. That said, many children may see their own participation in military life as emancipatory, and it remains crucial not to dismiss or condescend to those with such self-perceptions. One important path forward is to ensure that the best interests

28 Drumbl 2012: 13.

29 See Van Engeland in this volume. 
of the child principle, situated in Article 3 of the UN Convention on the Rights of the Child (CRC), be fully actuated. Respecting best interests means foregrounding the voices of the children themselves. This Research Handbook seeks to vivify an ecology in which children are treated with respect, are listened to and not spoken over (or for) and remain included in decisions that affect them, others and everyone. Protective policies predicated upon children being constructed as enfeebled before and during conflict may counterproductively result in children persistently being treated as enfeebled after conflict.

\section{RESPONSIBILITY FOR CHILD SOLDIERING: LAW, POLICY AND BEST PRACTICES}

When is recruitment of children into armed groups or armed forces unlawful? The CRC provides that states 'shall take all feasible measures to ensure that persons who have not attained the age of fifteen years do not take a direct part in hostilities' ${ }^{30}$ In terms of recruitment, states 'shall refrain from recruiting any person who has not attained the age of fifteen years into their armed forces'. ${ }^{31}$

Many states and transnational activists felt that the CRC protections were inadequate. This led to the entry into force in 2002 of an Optional Protocol to the CRC on the Involvement of Children in Armed Conflict (OPAC). ${ }^{32}$ As of 2018, 167 states are parties thereto. Article 1 of OPAC affirms that states 'shall take all feasible measures to ensure that members of their armed forces who have not attained the age of 18 years do not take a direct part in hostilities'. Article 2 mandates that states 'shall ensure that persons who have not attained the age of 18 years are not compulsorily recruited into their armed forces'. Article 3(1) then somewhat nebulously adds:

States Parties shall raise the minimum age for the voluntary recruitment of persons into their national armed forces from that set out in article 38, paragraph 3, of the [CRC], taking account of the principles contained in that article and recognizing that under the [CRC] persons under the age of 18 years are entitled to special protection.

Article 3(1) mandates states to increase the threshold age for the voluntary recruitment of persons into their national armed forces beyond 15 - ostensibly, then, at the very least to 16. Pursuant to the OPAC, then, 16- and 17-year-olds can be recruited into national armed forces. Their recruitment, however, is subject to strict conditions. It must be 'genuinely voluntary' and 'carried out with the informed consent of the person's parents or legal guardians'; recruits are to be 'fully informed of the duties involved in such military service'; and they must 'provide reliable proof of age prior to acceptance into national military service'. ${ }^{33}$

30 CRC, art. 38(2). See also Additional Protocol I, art. 77(2) and Additional Protocol II, art. 4(3)(c).

31 CRC, art. 38(3) (adding that 'In recruiting among those persons who have attained the age of fifteen years but who have not attained the age of 18 years, States Parties shall endeavour to give priority to those who are oldest').

32 For further discussion of the OPAC, see Hanson and Molima in this volume.

33 OPAC, art. 3(3). 
Each state party to the OPAC is required to deposit a binding declaration upon ratification or accession that sets forth its minimum age of voluntary recruitment as determined under national law. Approximately three-quarters of states that have filed declarations list minimum ages of voluntary recruitment of 18 or, in a handful of cases, older. A generalized practice, therefore, is emerging (at least if the metric is to undertake a head-count of states). Among the minority of states that have declared an age lower than 18 , most adopt 17.

The OPAC is more restrictive in cases of armed groups. These groups 'should not, under any circumstances, recruit or use in hostilities persons under the age of 18 years'. ${ }^{34}$ What is more, pursuant to Article 4(2), states agree to take 'all feasible measures' to criminalize such practices. State responsibility therefore arises, at least in theory.

A number of other instruments - both international and regional - also address the recruitment of children into armed forces or armed groups. The International Labour Organization's Convention No. 182 on the Prohibition and Immediate Action for the Elimination of the Worst Forms of Child Labour defines a child as a person under the age of $18 .{ }^{35}$ This convention explicitly links 'forced or compulsory recruitment of children for use in armed conflict' to 'slavery or practices similar to slavery' and obliges ratifying member states to 'take immediate and effective measures to secure the prohibition and elimination' thereof. ${ }^{36}$ The African Charter on the Rights and Welfare of the Child, which came into force in November 1999 defines a child as 'every human being below the age of 18 years' and requires parties to 'take all necessary measures to ensure that no child shall take a direct part in hostilities and refrain, in particular, from recruiting any child' ${ }^{37}$

CRC Article 38(1) requires that states 'undertake to respect and to ensure respect for rules of international humanitarian law applicable to them in armed conflicts which are relevant to the child'. How does international humanitarian law approach children? This is a very complex topic. At its core, international humanitarian law generally requires that children receive 'special protection' and remain the 'object of special respect' ${ }^{38}$ This applies directly to how child fighters ought to be detained and treated upon capture. Operationalizing these protections in the context of armed conflict becomes particularly fraught with regard to the poignant question of whether children can be targeted on the battlefield. Presumptions of protected civilian status and special respect would, at a very minimum, inform rules of engagement.

International criminal law also specifically addresses responsibility for child soldiering. As it currently stands, whether in international or non-international armed conflict, the conscription, enlistment, or use of children under the age of 15 to participate actively in hostilities is a war crime to which individual penal responsibility attaches. Prosecutions have occurred at the Special Court for Sierra Leone (SCSL) and the International

OPAC, art. 4(1).

Art. 2.

Arts 1,3(a).

See also Odongo in this volume.

38 See, e.g., Additional Protocol I, arts 77(1), 77(3), 77(4) (this last article states that '[i]f arrested, detained or interned for reasons related to the armed conflict, children shall be held in quarters separate from the quarters of adults, except where families are accommodated as family units'); Additional Protocol II, art 4(3). 
Criminal Court (ICC). ${ }^{39}$ In fact, the ICC issued its very first conviction solely on charges of unlawful recruitment. Thomas Lubanga, a rebel leader in the DRC, was sentenced to 14 years' imprisonment. Jurisprudence from the ICC and SCSL discussed throughout this Research Handbook has clarified important aspects of this war crime, along with offences such as forced marriage (as a crime against humanity falling under the category of other inhumane acts), sexual enslavement and sexual violence. ${ }^{40}$ Individual criminal responsibility for the illicit recruitment of children is also entering national criminal jurisdictions. As the age of unlawful recruitment inches towards 18, it may also be that the scope of individual criminal responsibility for such recruitment also moves upwards to 18 .

\section{RESPONSIBILITY OF CHILD SOLDIERS: LAW, POLICY AND BEST PRACTICES}

Child soldiers suffer crimes, and child soldiering is a crime, but child soldiers also may commit crimes - including grievous atrocity crimes - against adults as well as children. What are the consequences that arise for child soldiers in such instances? Although criminally prosecuting child soldiers for their alleged involvement in acts of atrocity is technically permissible under international law, hardly any such prosecutions have taken place before international or internationalized penal institutions. ${ }^{41}$ Moreover, such a move is increasingly viewed as inappropriate and undesirable. ${ }^{42}$

The constitutive statutes of the International Criminal Tribunal for the former Yugoslavia (ICTY, 1993) and the International Criminal Tribunal for Rwanda (ICTR, 1994) offered no guidance regarding the minimum age of criminal responsibility. The Rome Statute of the International Criminal court has no jurisdiction over any person who is under the age of 18 at the time of the alleged commission of the crime. ${ }^{43}$ The Statute of the Special Court for Sierra Leone limited the SCSL's jurisdiction to defendants who were 15 years of age or older at the time of the alleged offence, though incarceration was not a possible sanction for defendants under the age of $18 .{ }^{44}$ In any event, the SCSL's first Chief Prosecutor promptly and unequivocally stated that he would never prosecute children under the age of 18 , including child soldiers, inter alia because they do not bear

39 The International Military Tribunal at Nuremberg prosecuted Baldur von Schirach for inter alia his leadership of the Hitler Jugend. Von Schirach was acquitted of this charge (though he was convicted of other crimes against humanity and sentenced to a 22-year term). His successor, Artur Axmann, was tried before a De-Nazification court which sentenced him to a prison term of 39 months; in 1958 a West Berlin court fined him for having indoctrinated German youth with Nazi ideology.

40 The ICC may also award reparations to victims, including children under the age of 18 . A reparative order may be made directly against a convicted person, although such individuals are generally impecunious, or may also be effected through a separate trust fund for victims. Rome Statute, art. 75(2).

41 See Kaushik and Freeland in this volume; Holá and Bouwknegt in this volume.

42 Paris Principle 8.6 flatly states that '[c]hildren should not be prosecuted by an international court or tribunal'.

43 Rome Statute, art. 26.

44 SCSL Statute, arts 7(2), 19(1). 
the greatest responsibility ${ }^{45}$ But international institutions can prosecute and incarcerate former child soldiers who committed crimes as adults. Currently, Dominic Ongwen faces prosecution at the ICC in The Hague on many counts of horrific crimes. Ongwen himself was a violently abducted and abused child soldier who came of age in the LRA. ${ }^{46}$

It remains unclear how these tendencies towards non-prosecution of those under 18 map onto national legal practices, in particular, in the case of children associated with 'terrorist' groups or 'violent extremists'. Children may be prosecuted for all sorts of crimes at the national level, including atrocity crimes, and, of course ordinary common crimes. Rwanda, for example, tried and convicted many individuals, who had been children at the time of their crimes, of genocide following the 1994 tragedy that engulfed that country. ${ }^{47}$

National ages of criminal responsibility may be gradated. This means that jurisdictions establish a minimum age of criminal responsibility and a separate age of adult criminal responsibility. Article 40(3)(a) of the CRC requires states to seek to promote the establishment of 'a minimum age below which children shall be presumed not to have the capacity to infringe the penal law' but sets no such age. The Committee on the Rights of the Child, a UN treaty body of independent experts which helps monitor state compliance with the CRC, has concluded that 12 years should be the 'absolute minimum' age of criminal responsibility, and has encouraged states to increase it to a higher age level, commending states that have adopted the age of 14 or $16 .^{48}$ The CRC restricts the use of certain sanctions for juveniles. It permits the 'arrest, detention or imprisonment of a child', but requires that these measures 'shall be used only as a ... last resort and for the shortest appropriate period of time' ${ }^{49}$ It precludes the death penalty and life imprisonment without parole as sentences for children who are convicted of offences. Where children are deprived of liberty, the CRC requires that they 'be separated from adults unless it is considered in the child's best interest not to do so'. ${ }^{50}$ The CRC specifies a minimum level of due process protection for children subject to criminal proceedings, which broadly reflects due process guarantees for anyone coming into conflict with the law, but it also encourages the development of enhanced frameworks attuned to their specific needs. The CRC does not favour incarceration, preferring instead rehabilitation and reintegration. That said, the CRC does not bar incarceration.

An entirely separate question, which should not be occluded by conversations regarding the criminal responsibility of minors for international crimes, is the positive role that transitional justice initiatives other than criminal trials can play in the rehabilitation, reintegration and recovery of such children, and perhaps better finesse the dual position of such children as victims and perpetrators. Such initiatives include truth commissions,

45 SCSL Public Affairs Office 2002.

46 See Ramos in this volume.

47 Barrett 2019.

48 CRC Committee 2007: [30] and [32]. CRC state parties are required to submit regular reports to the Committee.

49 CRC, art. 37(b) (also requiring that '[n]o child shall be deprived of his or her liberty unlawfully or arbitrarily'). Turning to international humanitarian law, Article 68 of the 1949 Fourth Geneva Convention precludes imposing the death penalty on 'a protected person who was under eighteen years of age at the time of the offence', as do both of the 1977 Additional Protocols.

50 CRC, art. 37(c). 
ceremonial rituals, ${ }^{51}$ art and drama therapy, community service and other processes to rebuild trust among war-affected youth and their afflicted communities. These initiatives may assist in demobilization programmes, encourage durable shifts to civilian life, promote gender equality and dissuade from recidivism. It remains unclear, however, how welcoming the international legal imagination is of the multidimensional involvement of children (as victims, witnesses and as perpetrators) in transitional justice institutions. ${ }^{52}$ Grace Akello bemoans this reticence in her contribution to this Research Handbook.

\section{THIS RESEARCH HANDBOOK: STRUCTURE AND RATIONALES}

This Research Handbook contains 23 chapters. Contributors hail from six continents. Contributors approach the subject matter from a great diversity of disciplinary perspectives: literary theory, sociology, ethnography, social work, psychology, political science, criminology, medical anthropology and law. The contributors themselves remain deeply diverse and reflect a wonderful mix of established scholars and emerging voices - as well as practitioners and theoreticians - who, when assembled, present the very latest in research, entrepreneurialism and experiences with state-of-the-art policy implementation. Methodologies, too, are pluralistic: ranging from ground-breaking empirical studies, qualitative research and rich interview data to literary analysis and doctrinal review. Throughout, an emphasis is placed on the many stages of the life-cycle of the child soldiering experience: from recruitment, to the period in which the child is associated with armed forces or armed groups, and then to disarmament, demobilization and - by far the trickiest stage - reintegration.

While a broad swathe of jurisdictional case studies is referenced throughout the chapters, those unfurled with the greatest intensity include Colombia, Sierra Leone, Uganda, the Democratic Republic of the Congo, Nigeria (and the Lake Chad basin), the United Kingdom, the United States, Afghanistan, ISIS (in Iraq and Syria), the Philippines and Liberia. The chapters bind together in that, regardless of origin and methodology, each involves application of academic rigour to conventional wisdom that in some places reinforces, in others unsettles and, in some instances, upends it. Contributors to this edited collection are also diverse in terms of what they recommend, suggest or imply. As editors, our goal was never to present a pointed or monolithically normative volume with all entries singing off the same hymn sheet. Rather, in these pages we hope to bear witness to the kinetic energy that fills the field of child soldier studies. The end product, we feel, is not to be overly manicured and curated but, instead, to stand on its own, assuring the

\footnotetext{
51 See Barrett in this volume.

52 See, for example, how the Paris Principles address truth-seeking and reconciliation mechanisms:
}

8.15 All children who take part in these mechanisms, including those who have been associated with armed forces or armed groups should be treated equally as witnesses or as victims.

8.16 Children's participation in these mechanisms must be voluntary. No provision of services or support should be dependent on their participation in these mechanisms. 
autonomy and independence of the author and reader. To be sure, when authors speak to each other and address similar themes, whether in agreement or in dissent, we highlight the cross-pollination through references and other signposts.

As editors, we have constellated this Research Handbook around four themes, represented in the following Parts: (I) The Concept and Construction of the Child Soldier; (II) Conduct: Agency, Capacity and Resilience; (III) Encounters with the Law; and (IV) Afterworld(s)/Afterwards: Transitional Justice and Beyond. We have placed the chapters in each 'theme' based on substantive 'fit', but we also have made a conscious effort to include within each theme authors at various career stages, various disciplines, various backgrounds and concerning themselves with various jurisdictions. To be sure, these parts and themes are not hermetically sealed. Plenty of cross-overs and pass-throughs arise. The book ends with an elegant epilogue by Nesam McMillan, who - invoking W.E.B. Du Bois - encourages reflection on what it means to be a 'problem', that is, what it means for the child soldier to see him or herself framed and mirrored by others as problematic. McMillan calls for a granular, humanistic approach to the experiences of militarized children that prioritizes careful and sustained engagement with actual lives and the actual ways in which those lives are lived.

\subsection{Part I: The Concept and Construction of the Child Soldier}

How are child soldiers conceived and perceived across time, place and narrative method? When does construction become concoction? Constriction? Constellation? What is the place of the subject in the concept? This part weaves together contributions that unspool how the child soldier is imagined. This part is as much about looking (and who looks) as it is about seeing (and who is seen).

Mohamed Kamara opens with a powerful, raw and visceral exposition of the child soldier as constructed in literature - whether fiction or autobiography. Kamara entitles his chapter 'In Search of the Lost Kingdom of Childhood' and peppers his analysis with a broad array of literary and cinematographic references. He focuses on three novels: Ahmadou Kourouma's Allah Is Not Obliged, Emmanuel Dongala's Johnny Mad Dog and Ishmael Beah's A Long Way Gone. Kamara examines how (and why) child soldiers become conceptualized as celebrities. He unpacks the child soldier as a character in popular culture. He does so to nudge the reader to interrogate what is to be learned generally from the stories of celebrity child soldiers since, after all, 'every person comes from somewhere and has a story'. Like McMillan, Kamara also invokes W.E.B. Du Bois, in this case Du Bois' writing about the double consciousness that resounds in The Souls of Black Folk, the 'two-ness' of being 'an American, a Negro', which Kamara suggests is relational to the 'oxymoron' of the child soldier. As for agency, well, can children 'make a heaven of hell, after grown-ups have done the opposite'?

Ana María Jiménez follows with a comprehensive account of the effects of legal categorization upon the status of militarized children in Colombia. Her chapter 'Challenges for the Protection of Child Victims of Recruitment and Use in an Era of Complex Armed Conflicts: The Colombian Case' begins with a deft summary of the changing nature of armed conflict, drawing on the history(ies) of conflict in Colombia as an illustration. What is conflict? What is peace? What are the in-betweens? Jiménez follows with a detailed survey of current efforts in Colombia to negotiate and sustain peace through law. 
She identifies a great contingency, however: a contingency of conceptualization and construction. Are militarized children in Colombia child soldiers? Are they child criminals? Are they child terrorists? Rebels? Bandits? Agents of the state? Or just children? In the Colombian case, the answers to these questions transcend semantics and nomenclature. They are deeply consequential. Jiménez adroitly exposes how the way the child is classed bears directly upon that child's prospects for reintegration, resocialization and rehabilitation. Jiménez laments how the 'generally shifting nature of armed conflict' fits poorly with law's predilection for categories, templates and flowcharts, leading in her words to 'blind spots'. Her work is all the more topical in light of the opening of investigations in Colombia in 2019 with regard to the mass recruitment of 6,000 children during the decades of conflict.

Chapter 3 is titled 'The Construction of Gender in Child Soldiering in the Special Court for Sierra Leone'. Authored by Valerie Oosterveld, this chapter unearths the gendered nature of violence in Sierra Leone. Oosterveld illustrates how testimony before the Special Court for Sierra Leone (SCSL) revealed how rebel groups targeted both boys and girls. In the case of girls, the SCSL authenticated the vulnerability of girls to sexual violence and the terror of forced marriage (determined to be a crime against humanity). Oosterveld's granular and exacting review of the SCSL's work highlights how judges and prosecutors applied constructions of gender in order to secure crucially important justice goals, notably when it comes to condemning horrific gender-based violence against girls, but also how that very same process led to omissions, elisions, invisibilities and distortions. One example is 'silence on sexual violence directed against boy soldiers'. Essentialized constructions of the child soldier experience, while facilitating criminal convictions for adult abusers and exposing certain kinds of violence, may simultaneously occlude other forms of abuse. Law's light leads to law's shadows. Law reveals as it conceals.

Chapter 4 is also about gender and atrocity. This chapter picks up and advances Oosterveld's charge. It squarely addresses how the international legal imagination overlooks sexual violence against boys. "We Were Controlled, We Were Not Allowed to Express Our Sexuality, Our Intimacy Was Suppressed": Sexual Violence Experienced by Boys' presents extensive interview data collected by Omer Aijazi, Evelyn Amony and Erin Baines in northern Uganda. This chapter tears the wrapping off the 'conceptual trap of girls and women as victims and boys and men as perpetrators found in second wave feminist legal studies' and resonates with words from what Derrick Bell has, in a different context, called the 'faces at the bottom of the well', that is, those who have never been thought of as having suffered nor have ever been asked about their experiences. ${ }^{53}$ It opens with an encounter between Fred, a boy soldier, and Erin Baines, a Canadian academic, acknowledging that, amid her many years of work in northern Uganda, ' $[\mathrm{t}$ ] his was the first time [she had] knowingly spoke[n] to a male survivor of wartime rape'. The remainder of this chapter presents the words of the boys themselves, words about their worlds. These words are tales of counter-narratives: the strict regulation of sexual relations in the Lord's Resistance Army; the 'forged' nature of forced marriage relationships and the pain that was inflicted on both 'wives' and 'husbands'; the choicelessness faced by many boys; powerful women who 'preyed on young boys' and used them for 
sex; and the sexual assault of boys by senior male commanders. Aijazi, Amony and Baines conclude by urging 'legal feminist frameworks' to 'sufficiently make room for boys and men in their advocacy and policy efforts' while also encouraging that another limiting concept be shed, if not shredded, namely 'heteronormative ideals of manhood and masculinity'.

In Chapter 5, Karl Hanson and Christelle Molima highlight disconnects between transnational conceptions of child soldiers and how child soldiers see themselves. They urge that dominant constructions that approach children 'as the helpless objects of wellmeaning interventions' be discarded and instead replaced with a framework of 'living rights, social justice and translations' that 'include[s] children and young people's own conceptions of their rights'. In this vein, then, Hanson and Molima wish for the child soldier no longer to be an object that is peered at through outsider adult lenses. Entitled 'Getting Tambo Out of Limbo: Exploring Alternative Legal Frameworks that are More Sensitive to the Agency of Children and Young People in Armed Conflict', this chapter elevates an emancipatory view of children's rights that energetically ensures that child soldiers remain key stakeholders in how they are seen. This means that they have rights to present themselves, be heard, associate, engage and participate. Hanson and Molima link debates over child soldiering and the unlawfulness of recruitment, with a much broader discussion about youth activism and empowerment generally.

Part I concludes with Rhys Crilley's contribution: 'This Is Belonging: Children and British Military Recruitment'. Crilley airs constitutive debates over child soldiers in many ways, notably by challenging assumptions that non-state actors in the Global South embroiled in feral wars accurately reflect the 'problem' of child soldiering. Crilley writes about how an influential Western state, the United Kingdom, through active state practices and deployment of social media, recruits youngsters into military forces from the age of 16. Crilley thereby disrupts the shibboleth as to 'who' constitutes the 'universalized' child soldier. Crilley also exposes what he calls a 'child soldier culture'. Rather than seeing child soldiering as an inevitable outcome of uncontrollable wars, Crilley underscores how the state may deliberately stoke such a culture based on a marketing strategy that invokes the emotions of camaraderie, play and community. On this note, then, Crilley's work contributes to the epistemology of how recruitment happens. Crilley's work may well point to broader patterns at play everywhere, whether in the Global North or Global South, that derive from the push and pull of global capital, loneliness, poverty and the yearning to belong.

\subsection{Part II: Conduct: Agency, Capacity and Resilience}

How do children end up in fighting forces? What do they do once there? How do they recount their experiences? The contributions in this part tackle tough questions about children's agency, capacity and resilience. These contributions take the form of a series of national case studies, including in several instances ground-breaking interview data collected through extensive fieldwork. Structuring this part in this serial fashion permits a granular appreciation of the divergent experiences of child soldiers and gestures towards the shortcomings of over-generalization and monochromatic assumptions. This part also reveals how accurate understandings of the lives of children while militarized lays the groundwork for their successful 'exits' from militarization, and, thereby, presages some of 
the conversations about decommissioning, demobilization and reintegration that infuse Part IV of this edited collection.

The first chapter herein explores the role and conduct of children in military forces from a historical perspective, specifically children in the US army during the Revolutionary War and the Civil War. This chapter - Chapter 7 - also examines children in US armed forces and UK armed forces during the First World War. Authored by David Rosen, 'Child Soldiers in Historical and Comparative Perspective: Creating a Space for Data-Driven Analysis' meticulously documents historical patterns of recruitment, youth volunteerism and the effects of national conscription on children in the armed forces. Rosen laments that, when it comes to researching child soldiers, currently the 'language of advocacy' has become adopted as the 'language of inquiry'. For Rosen, this obfuscates accurate portrayals of how and why children become militarized, what they do in those contexts and who is now recruiting them (Rosen maintains that the focus should be on non-state actors). For Rosen, a less didactic account of child soldiers is desirable: practices cannot be eliminated without being accurately understood. Rosen also warns of the dangers of advocacy imagery, notably the construction of the modern child soldier as a faultless passive victim. According to Rosen, the rhetorical puffery of such imagery fuels the unequal treatment of children. He points to the wretched way the US abused child detainees in the 'War on Terror'. Rosen makes a powerful argument that the lack of 'data-driven analysis' that undergirds the faultless passive victim image of child soldiers 'permits the emergence of a counter-narrative, when politically expedient ... of the purposeful and dangerous child terrorist, which becomes deployed when the interests of powerful Western states may be seen as threatened'.

Chapter 8 addresses 'The Voiceless Child Soldiers of Afghanistan'. Anicée Van Engeland argues in favour of contextualization when considering child soldiering, notably, to take account of cultural and traditional factors. She explores the concepts of agency and child soldiers as social navigators and circumscribed actors and applies these theoretical concepts to Afghanistan. Van Engeland concludes that child soldiers in Afghanistan exercise little in terms of what can be called agency. They are "pawns in a game' who are 'perceived as duty-bearers born into a world of expectations, rather than rights-bearing subjects'. Van Engeland argues that 'the recruitment of child soldiers in Afghanistan is the outcome of a security context that has shaped traditional, religious, cultural and customary behaviours, making it acceptable, if not normal, to recruit children as combatants'. Van Engeland's contribution addresses questions of how to speak of - and how to redress - child soldiering at the extreme ends, where children in her view simply have no 'room to manoeuvre' because of embedded gerontocracy, control, abduction and deprivation.

In Chapter 9, Mia Bloom considers children implicated in acts of terrorism. She principally focuses on ISIS but offers readers an array of comparative insights and impressions from a multiplicity of groups variously determined to be terroristic, extremist or armed in nature. Hence, 'Weaponizing the Weak: The Role of Children in Terrorist Groups' includes references to the Liberation Tigers of Tamil Eelam in Sri Lanka, Maoists in Nepal and armed factions in Sierra Leone, among others. Bloom paints a rather composite picture of children: whereas in some instances the amount of agency exercised is minimal, in other cases it may be notable. She contrasts 'child soldiers' and 'children recruited by militant terrorist organizations'. Bloom's comprehensive chapter notes significant 
variation among groups in how they approach children, including pointedly in the context of gender and role differentiation, once again suggesting the need for heterogeneity in analysis rather than assumptions about uniformity. Bloom carries the reader through each stage of ISIS' use of children, which she characterizes as 'an institutionalized form of child abuse': recruitment, socialization, desensitization, schooling, selection, training, specialization and stationing. She delves into the conduct of children and adults - what actually happens - at each of these stages. This chapter, in a manner similar to Crilley's, also offers a fascinating vignette into the manipulation of youth through social media, including as it does a detailed discussion of ISIS' deployment of internet resources.

Chapter 10 concerns the Philippines, specifically child soldiers in the Lanao provinces located on Mindanao Island. This chapter presents the fascinating and crucially probative results of a descriptive-qualitative study (personal interviews and focus-group discussions) that, through the voices of Philippine child soldiers, brings to light the factors that influenced them to join the armed struggle by a number of groups (including the Moro Islamic Liberation Front) against the government. This ground-breaking study was conducted by a team of five researchers: David N. Almarez, Ajree D. Malawani, Sittie Akima A. Ali, Princess Mae S. Chua and Primitivo C. Ragandang III. This chapter begins by discussing the history of violence in Mindanao, presents processes of recruitment, explains the training and roles of children, identifies the centrality of madrasah education at all stages and finally offers wise recommendations to ensure the reintegration of affected youth (notably educational reform). Throughout, the authors present the day-to-day activities and motivations of their interviewees. What is more, the authors also present accounts of the conduct of children in actual armed conflict, their relationships with each other and their families, as well as their experiences of escape. 'Retracing the Journey of Child Soldiers and Looking for the Path to Return Them Home: A Report from Southern Philippines' is a treasure trove of information, insights and suggestions.

Myriam Denov, in Chapter 11, also shares the highly informative results of extensive fieldwork. Between June 2015 and December 2017, Denov participated in a series of interviews in northern Uganda with 71 children born in captivity (i.e. children born as a result of acts of war-time rape) in the Lord's Resistance Army. The results of these interviews are at once poignant and inspiring. Denov foregrounds the voices of her interlocutors, bringing visibility to this largely invisible set of children. She pushes the epistemic frontiers beyond the women and girls who were victims of repeated acts of sexual violence so as to begin to 'document the realities of their children who were born of conflict-related sexual violence, and in some cases, raised within the LRA'. Denov nimbly preserves the autonomy of these voices but neatly arranges her chapter so that readers learn of the children's perspectives on home, family, identity, belonging and reintegration. Voices speak of the 'bush' as 'home' and elaborate upon the rapport between home and identity and family when one's home is constantly moving and in flux; they talk of trainings to use weapons and of children's relationships with their mothers and fathers in captivity, as well as musing on marginalization and reintegration, including for Denov the 'highly disconcerting' fact that 'participants often identified the state of war and captivity - when violence, upheaval, deprivation and ongoing terror were at its height - as better than life during peacetime'. Denov concludes 'Children Born of Conflict-Related Sexual Violence within Armed Groups: A Case Study of Northern Uganda' with some 
programmatic recommendations tailored to the needs of children born into captivity as a subset of child soldiers.

Chapter 12 is entitled 'Social Reintegration Following Armed Conflict in Northern Uganda: How Former Child Soldier Young Mothers Use Symbolic Resources'. Here, Fiona Shanahan and Angela Veale share results from a qualitative study they conducted with mothers in northern Uganda. These results are presented in some instances as lively transcripts of conversations. Shanahan and Veale illuminate how these mothers deployed symbolic resources, which they understand to mean 'specific cultural elements used intentionally by people to facilitate developmental change'. These include songs, images, prayers and rituals. Shanahan and Veale present the vivacity of such symbolic resources in northern Uganda: folktales; riddles - many riddles - including one of a rooster and a millipede; and jokes. These symbolic resources helped the women 'mediate their sense of self' and also served a pedagogic function for their children. Shanahan and Veale consistently emphasize how their interlocutors signalled the continuities of their civilian and rebel identities, in contrast to conventional wisdom that presents war as discontinuous, as a rupture and as a break - therefore presenting a new perspective on the peace-war-peace transition. Shanahan and Veale unwrap for the reader the coping mechanisms that mothers availed themselves of while in captivity as child soldiers, thereby attesting to the touchstone themes of resilience, capacity and agency - in particular, the idea of 'internal' agency in contexts where the women were unable to bring about change in their 'external circumstances'. Does an individual's action constitute agency if she is unable to effect external change? Shanahan and Veale certainly show this question in a far more refined light.

\subsection{Part III: Encounters with the Law}

Law is a lurker throughout this edited collection. Part III, however, features contributions that squarely address the encounters that child soldiers have with the law. What are these moments like? Are they smooth, joyful, abrupt, pained - or all of the above? How does the law approach the child? What does the law make of the child who soldiers? How does the law leave that child after having involved the child in its processes? What are the consequences to adults who unlawfully recruit children? While 'law' in this part is understood broadly, the central focus lies with international and regional instruments in the areas of human rights, criminal law and refugee and asylum protection. In terms of institutions, this part primarily considers courts (including the International Criminal Court), although it also actively involves administrative bodies, fact-finding missions and human rights institutions.

In Chapter 13, Godfrey Odongo studies an innovative legal regime: the African Charter on the Rights and Welfare of the Child adopted under the auspices of the African Union. State compliance with this Charter is overseen by an Expert Committee, which issues important reports and conducts fact-finding missions. Odongo details the substantive law of the Charter when it comes to child soldiering, sets out procedures and processes and digs into the content of many of the communications issued by the Expert Committee. He thereby adds fascinating new dimensions to the discussion of 'law': regional instruments, state responsibility, reporting requirements and the power of naming and shaming (instead of criminal sanction) to achieve compliance with agreed-upon standards. 'The 
Regional African Legal Framework on Children: A Template for More Robust Action on Children and Armed Conflict?' also includes excerpts from the reports themselves, including ones concerning the Central African Republic and South Sudan, which present a glimpse at the literature of fact-finding and the ability of such reporting to authenticate and narrate incidents not only of child soldiering but other violations, including hazardous child labour. What is more, Odongo draws parallels and contrasts between the African Charter and the CRC as well as the work of their respective monitoring bodies.

The theme of child labour is expanded robustly in Chapter 14, 'Minors and Miners: Accountability Beyond Child Soldiering in the Democratic Republic of Congo'. In this chapter, Sharanjeet Parmar and Yann Lebrat present results from qualitative fieldwork they undertook in conflict-riven gold mining areas in the DRC, which they merge with the content of open source data. They argue that the 'problem' of child soldiering cannot be understood, let alone redressed, without confronting the realities of child labour and economic crimes. Parmar and Lebrat isolate the illicit mining of conflict materials as a key driver of instabilities and illegalities, including child soldiering. In addition to providing a comprehensive exposé of mining in the Misisi area of the DRC, including the discomfiting and shady role of Congolese armed forces, Parmar and Lebrat offer an array of reformist recommendations. These include ways in which to improve the efficacy of the UN Security Council on matters of child soldiering, options for judicial accountability and the pursuit of criminal liability for economic crimes (including pillage and corporate responsibility).

In Chapter 15, Nikila Kaushik and Steven Freeland advance the discussion beyond how law can shame or punish states and individuals who may harm children to the very tricky question of the penal responsibility of children themselves when they harm others. This is an encounter with the law, to be sure, but an encounter of a very different nature. How does the law approach the child atrocity perpetrator? How should it? How ought the law to permit someone harmed by a child to seek justice? 'Crimes Committed by Child Soldiers: An Argument for Coherence' provides a detailed summary of international law and practice. Kaushik and Freeland note how the international legal imagination is reluctant - indeed, most hesitant - to prosecute minors before international penal institutions for international crimes. They welcome this reluctance. That said, they wisely flag the unprincipled nature of this reluctance. They rue how the intersection of minors with international courts and tribunals has become a bland jurisdictional move rather than a thoughtful jurisprudential journey. In the end, Kaushik and Freeland urge more reflection and justification. They do so since '[p]reserving integrity in law making is fundamental to ensuring the place of the rule of law' and because '[a]d hoc law making is not to be celebrated, even if the results might appear to be sound on their face'.

Barbora Holá and Thijs Bouwknegt lead readers to encounters of a different kind, that is, between children, on the one hand, and the architecture, mechanics and formalities of international courtrooms, on the other. These encounters, regrettably, are neither felicitous nor reinforcing. On the contrary, Holá and Bouwknegt find that they are often 'inappropriate, uncomfortable and uneasy'. Holá and Bouwknegt develop an explorative empirical study that zooms in and out of the courtroom (specifically the ICC and SCSL) to disentangle the child from the procedures. What is to be learned? For starters, children called upon to serve as witnesses - including when testifying against the adults who may have recruited them - often are seen as lacking in credibility. Children who speak of the harms they have endured shrink in size rather than grow in stature. '[A]dversarial adult 
courtrooms' diminish children to 'fragile and malleable figurants' and 'ghost victims'. In the end, the eclectic title of Chapter 16 captures the mood: 'Child Soldiers in International Courtrooms: Unqualified Perpetrators, Erratic Witnesses and Irreparable Victims?' While beyond the scope of this chapter, this leads to ruminations central to this Research Handbook as a whole - one being: how to change the mood? How to refresh this scenario, just because, and add some spice - well, perhaps by opening wide a window to wonder about all the adult 'rules' and to welcome surprising irregularities. That way, when someone - including a child, a teenager - slips up at a trial, messes up, well, that's just a slip: it's not a fall, flail or fail. What about venues other than courts for war-affected youth to build narratives, nurture empowerment and assess obligations?

Chapter 17 is entitled 'Dominic Ongwen on Trial: Problematizing Definitional Boundaries and Exploring the Possibilities of Socialization'. Carse Ramos delivers a sensitive and nuanced depiction of Dominic Ongwen - formerly a Brigadier Commander in northern Uganda's Lord's Resistance Army - who is on trial at the International Criminal Court. Ongwen faces 70 charges of crimes against humanity and war crimes, the most ever brought at the ICC, including gender-based violence. Ongwen also is singular in a different manner, namely, he is accused of crimes that he himself had endured after having been brutally abducted into the LRA as a child. Ongwen came of age in this armed group. The Ongwen trial, then, reflects the encounter of a former child soldier with the solemnity of a courtroom in The Hague and the categorical angularity of the law. How to speak of his childhood? Should it matter? Questions of duress, mitigation, responsibility, justice and deterrence abound. Mostly, however, Ramos encourages us to reflect on the painful realities that victims can become victimizers, the persecuted can persecute and violence can become a tool of survival and self-promotion. She urges the incorporation of a sociological framework to map the encounters of former child soldiers with the prospect of their own penal accountability as adults.

The final piece in this part, 'Child Soldiers and Asylum - Duality or Dilemma?' (Chapter 18), doctrinally examines child soldiers' encounters with refugee law. Joseph Rikhof observes that children in conflict zones putatively may face well-founded fears of persecution, which would entitle them to make asylum claims. Yet, one well-known bar to an otherwise eligible refugee claimant is if there is evidence that the claimant had persecuted others in the past, in other words, has committed serious crimes (including international crimes). In the case of child soldiers, then, how do national jurisdictions respond? Should the child be barred if evidence arises of implication in atrocity crimes? What if the participation therein was compelled - should duress operate as an exception to the bar? Rikhof provides a highly informative survey of the law and practice of a number of states and comes to the conclusion that the current state of affairs remains fragmented. In the end, while recognizing the need to acknowledge that some of these children may have committed serious crimes, Rikhof urges that consideration of humanitarian factors, including the special vulnerability of children and recognition of the stress and duress that encircles such children, 'should make their path to a permanent immigrant status easier than is the case for adults'.

\subsection{Part IV: Afterworld(s)/Afterwards: Transitional Justice and Beyond}

How do children 'leave' armed forces or armed groups? What is the afterworld of war like? The afterwards? This part examines disarmament, demobilization and 
reintegration (DDR) of former child combatants. ${ }^{54}$ Some mention is also made of reconciliation, perhaps as a fourth stage, further along. Reintegration is tricky: how is it to be measured? Recidivism and re-recruitment: how are these to be avoided? Contributions to this part assess the role of customs, magic, the mystical, therapy, education, civic life and job training in the reintegration process. Contributions also push the conversational frame into the realm of transitional justice, namely, how do collectivities reckon with human rights violations in cases where victims may victimize others in a manner that transcends criminal law (the limitations of which Part III addressed)? And, finally, what are the responsibilities of those, often outsiders, involved in DDR programming?

Jastine Barrett engages with indigenous forms of justice and assesses their role in reintegration, reconciliation and transitional justice initiatives for war-affected youth. Chapter 19, 'Navigating the Mystical: Child Soldiers and Reintegration Rituals in Northern Uganda' provides an overview of the main reintegration rituals used in the Acholi region for LRA returnees. Barrett underscores their mystical elements and then links these to the importance of the spirit world in Acholi cosmology. One fascinating take-away is that indigenous mechanisms may be perceived as both a form of justice and of cleansing. Barrett also provides valuable insights into how indigenous methods 'were seen by' UNICEF and other organizations as compatible or not with their institutional ethos. Her interviews with current and former staff members of such organizations yield crucially important data in this regard. In the case of UNICEF, Barrett concludes that it 'was open to all approaches provided that they did not conflict with child rights, in particular the key principle of the best interests of the child'.

Grace Akello, a medical anthropologist, also reports on her work with LRA returnees in northern Uganda. Akello assesses the limits of 'sensitizing' local communities into a carefully manicured imagery of child soldiers as passive faultless victims. In 'Child Agency and Resistance to Discourses within the Paris Principles in Rehabilitation and Reintegration Processes of Former Child Soldiers in Northern Uganda' (Chapter 20), Akello presents findings from her 12-month-long ethnographic study in Gulu District. This study involved observation of local and emergency aid agencies as they organized workshops to promote awareness about 'the innocence of' rescued LRA child fighters as part of the reintegration process. Akello concludes that one of the 'unintended consequences' of this approach 'was silencing victims of war violence who would have preferred disclosure, reparation and compensation'. Akello underscores how communities did not see the returnees in the way that practitioners didactically presented them, and, as a result, reintegration was not as effective as it otherwise might have been. She identifies high rates of returnees subsequently becoming involved in criminal activities. Akello urges that community perspectives be better taken into account, that a diversification of remedies be pursued in a transitional justice framework, that the Paris Principles be rethought and that a more nuanced view be embedded that recognizes that, in some communities,

54 See Casey-Maslen in this volume: 'Disarmament is the collection, documentation, control and disposal of small arms, ammunition, explosives, and light and heavy weapons of fighters. Demobilization is the formal and controlled discharge of active fighters from armed forces or other armed groups. Reintegration is the process by which former fighters acquire civilian status and gain sustainable employment and income.' 
'victims of war violence do not make a clear distinction between acts of violence committed by a child and any other acts of violence'.

Chapter 21 is entitled 'Children Associated with Boko Haram: Disassociation, Protection, Accountability and Reintegration'. Authored by Stuart Casey-Maslen, this chapter delivers a careful assessment of how best to return children abducted into Boko Haram to civilian life. Like Akello, Casey-Maslen questions the usefulness of the Paris Principles, but also the UN's Integrated Disarmament, Demobilization and Reintegration Standards (IDDRS), in dealing with children associated with armed groups. He urges a review of both of these documents. In the Lake Chad Basin, one major impediment to the reintegration of these children is the reality of their ongoing detentions at the hands of governments and security forces. These children, horribly abused by Boko Haram, face more human rights violations upon capture by governmental forces; Casey-Maslen documents these practices. Challenges to the reintegration of these children, however, remain fuelled (perhaps even legitimized) by fear and suspicion. From our perspective as editors, these challenges can be traced to the reality of imagery, namely, to how they are seen. And they are seen in a way similar to how the US sees 'terrorists' captured in Afghanistan, as set out in Rosen's chapter, namely, not as faultless passive victims. Instead, these 'terrorist' children, regardless of how they became recruited, are constructed as baleful, sinister, purposeful and incorrigible - to be feared like snakes in the grass, recalling Shakespeare's evocation of how Henry VI saw Richard, so hungry for the throne, as Richard (then Duke of Gloucester) is set to murder him. Henry exclaims: 'Teeth hadst thou in thy head when thou wast born/To signify thou camest to bite the world' ${ }^{55}$ Accepting the need for age-appropriate accountability for all children, Casey-Maslen offers wise counsel to policy-makers as to how to constructively approach children trapped in the securityfuelled context of operations dubbed as 'counterterrorism'. He also questions the concept of afterworld(s) and afterwards by emphasizing the need to adopt DDR measures while armed conflict is still ongoing.

Michael Wessells also worries - like Akello - about inadvertent effects. He elevates these concerns to a broad scale. In Chapter 22, 'Do No Harm: How Reintegration Programmes for Former Child Soldiers Can Cause Unintended Harm', Wessells writes about practitioner ethics. He argues forcefully that practitioners need to develop greater self-awareness so as to avoid and manage harmful negative externalities. Wessells' chapter therefore links DDR practitioners to all sorts of professionals who, in myopically pursuing their vision of the right thing to do, may hurt others, including the very individuals they intend to help. For Wessells these questions far transcend virtue ethics and good intentions - neither suffice. The goal is mindfulness of effects. Wessells identifies a number of key concerns. One is the excessive targeting of former child soldiers in a fashion that may engender reverse discrimination against them and actual discrimination against children affected by war but who had not been associated with armed forces or armed groups. A second is gender discrimination, namely, the dismissive treatment of girl soldiers. Another is the risk that programmes 'quietly trample children's participation rights'. Yet another is 'the neocolonial imposition of outsider categories' at the expense of local approaches, such as those analysed by Barrett, which may be rooted in cosmology. Wessells, again like

55 Shakespeare 1590: Act V, Scene 6, London, The Tower, 3048-3049. 
Akello, also warns about what happens when practitioners avoid holding former child soldiers accountable for their actions. In the end, these behaviour patterns on the part of practitioners may lead to former child soldiers being exposed to risks, such as labelling, re-recruitment and susceptibility to securitization.

Leena Vastapuu concludes this Part with an insightful piece - lyrically written in the first person - about her experiences in Liberia. In 'How to Find the "Hidden" Girl Soldier? Two Sets of Suggestions Arising from Liberia' (Chapter 23), Vastapuu is motivated to 'produce the kind of chapter I would have once yearned to read myself, preferably before embarking for Liberia for the very first time'. In this sense she follows beautifully from Wessells' input on practitioner ethics - and to do no harm - to speak of the ethics of observation. Writing from an autoethnographic perspective, Vastapuu 'describe[s] some of the challenges and successes' that she encountered in her work with and about former girl soldiers in Liberia between 2012 and 2014. She offers two sets of counsel: first to researchers and second to DDR officers. Vastapuu speaks of herself, to be sure, but does so accompanied with extensive lively text about her interlocutors in Liberia, the risks they took to photograph their current lives with cameras, the conversations that ensued and their roles as girls in the armed conflict that had raged throughout the country. Vastapuu addresses what we know about why girls get left behind in terms of DDR and makes suggestions for how to remedy that disturbing gap. She focuses on contradictions within DDR best practices that conspire to underserve women and girls.

\section{GAPS AND FUTURE DIRECTIONS}

Assembling any edited collection takes on a life of its own. The process generates its own energies and synergies - centrifugal and centripetal. The pneumatics and hydraulics of these movements lead to gaps and surfeits.

One gap we as editors have noted is geographic in nature. This Research Handbook does not address child soldiering, or the reintegration of former child soldiers, everywhere. Sri Lanka, although tangentially referenced by Mia Bloom in her chapter, presents as a lacuna. UNICEF estimates over 6,000 cases of child recruitment between 2003 and 2008 by rebels in Sri Lanka. The Liberation Tigers of Tamil Eelam (LTTE) - a secessionist group that fought the Sri Lankan government until its defeat in 2009 - turned extensively to child soldiers and child suicide bombers. ${ }^{56}$ Another Asian lacuna is Cambodia. The Khmer Rouge used youthful cadres in the 'killing fields' between 1975 and 1979. In 2018, the Extraordinary Chambers in the Courts of Cambodia convicted two elderly leaders of genocide, as well as charges related inter alia to sexual violence and forced marriage, and have thereby opened a further space to discuss the place of children as victims and victimizers. In the Americas, the involvement of children in narco-trafficking, and their association with groups that ply such trades, is a festering concern that merits closer attention.

As for surfeits? One is Uganda. Seven chapters base themselves in whole or in part upon the (post)conflict in Uganda. We could, moreover, have had even more about Uganda

56 For a vivid recounting of life as an LTTE child soldier in this conflict, see de Soyza 2012. 
in this Research Handbook but diverted some of those energies to other directions so as to mitigate against this surfeit becoming fulsome. What does this suggest? Why did this happen? Is this reflective of the Africanization of child soldier studies - a tendency that this Research Handbook laments and seeks to dilute? In this sense, then, perhaps this Research Handbook solidifies the exact tendency that it aims to dissipate. Or is it because jurisdictions that have become subject to international judicialization efforts, such as Uganda, attract more attention? Or is this traceable to the spectacular nature of the Lord's Resistance Army's violence, made viral in the Kony 2012 video? Or the ongoing place of conversations nationally in Uganda over the reintegration of formerly militarized children, which continue in 2019? These possibilities, all conjectures, certainly are not mutually exclusive, so the truth could well be a combination of all of them. That said, as editors we also feel that this surfeit opens a wonderful space for more textured analysis within one jurisdiction of a variety of themes and contrasting perspectives. In this regard, Uganda infuses each of the four sections of this book: concept, conduct, encounters with the law and the afterwards of transitional justice. This permits one contextualized strand in which to unwind the life-cycle of child soldiering.

\section{TO CLOSE WITH ANNIVERSARIES}

Recent and immediately upcoming years evince many anniversaries when it comes to international treaties and international organizations. A generation has now passed since the excitement of the 1990s, the thawing of the Cold War and what was (then) a heyday of internationalist institutionalism. The International Criminal Court has turned $20-$ an age of adulthood (though many say the institution is still in its infancy and finding its sea legs, having only convicted three individuals so far). The CRC turns 30 this year! The Rwandan genocide, which involved children as victims, perpetrators and liberators, took place 25 years ago; later that same year, 1994, the ICTR (now closed, its work 'completed') was established. Throughout all these anniversaries, commemorative (at times celebratory) events are planned and the progress narrative of international law and policy feted. This Research Handbook forms part of these patterns of acknowledgement and recognition. But as editors we hope to participate in slightly different ways. We hope to contribute through the lenses of nuance and subtlety, through critical engagement and by respecting the voices of the children themselves. We aspire to render the invisible visible, map the unmapped and chart new directions. Self-awareness is key, a point that Michael Wessells is blunt about: 'Practitioners need to adopt a self-critical stance, demonstrate a willingness to document and discuss openly the negative, unintended consequences of programmatic activities, and incorporate the lessons learned to adjust ...'57 Finally, as editors, we hope to bring an uplifting energy and upbeat cadence that focuses on adversity but also embraces capacities and potentialities and individualities. So, to end with the words of Kafka that initially opened this introduction, now twice repeated, we hope to render the child less slight and the adult less broad.

57 Wessells in this volume. 


\section{REFERENCED WORKS}

Alkousaa, R. 2018. 'German Military Turns to Under 18s to Boost Recruitment', Reuters World News (24 August)

Barrett, J.C. 2019. Child Perpetrators on Trial: Insights from Post-Genocide Rwanda (Cambridge: Cambridge University Press) (forthcoming)

Bell, D. 1992. Faces at the Bottom of the Well: The Permanence of Racism (New York: Basic Books)

CRC Committee [Committee on the Rights of the Child] 2007. 'General Comment No. 10: Children's Rights in Juvenile Justice' (UN Doc. CRC/C/GC/10) (25 April)

de Soyza, N. 2012. Tamil Tigress: My Story as a Child Soldier in Sri Lanka's Bloody Civil War (Pune: Mehta Publishing House)

Drumbl, M. 2012. Reimagining Child Soldiers in International Law and Policy (Oxford: Oxford University Press)

Drumbl, M. 2019. 'Children in Armed Conflict', in J. Todres and S. King (eds), Oxford Handbook on Children's Rights (Oxford: Oxford University Press) (forthcoming)

Kafka, F. 2018. Letter to Father (translated by K. Reppin) (Prague: Vitalis) (originally written 1919)

Lepule, T. 2018. "CChild Soldiers” are Terrorizing Cape Flats Communities, Says Study', Weekend Argus (13 May)

The Local 2018. 'German Army Recruits More Minors than Ever Before' (9 January 2018) [available at: https:/www.thelocal.de/20180109/german-army-recruits-more-minors-than-ever-before-report (accessed 26 November 2018)]

Machel, G. 1996. 'Impact of Armed Conflict on Children: Report of the Expert of the Secretary-General Submitted Pursuant to General Assembly Resolution 48/157' (UN Doc. A/51/306) (26 August)

SCSL Public Affairs Office 2002. 'Special Court Prosecutor Says He Will Not Prosecute Children' (press release) (2 November)

Shakespeare, W. 1590. History of Henry VI, Part III

Talbert, M. and Wolfendale, J. 2018. 'The Moral Responsibility of Child Soldiers and the Case of Dominic Ongwen' (Stockholm Centre for the Ethics of War and Peace) (6 March) [available at: http://stockholmcen tre.org/the-moral-responsibility-of-child-soldiers-and-the-case-of-dominic-ongwen/ (accessed 20 November 2018)]

UN Secretary-General 2018. 'Report of the Secretary-General on Children and Armed Conflict' (UN Doc. A/72/865-S/2018/465) (16 May)

UN SRSG for Children and Armed Conflict 2016. 'Children and Armed Conflict, Report of the Secretary-General: Annual Report Summary' [available at: https://childrenandarmedconflict.un.org/wp-content/uploads/2018/05/ Summary-Annual-Report-2016_Children-and-Armed-Conflict.pdf (accessed 28 November 2018)]

UN SRSG for Children and Armed Conflict 2018a. 'Annual Report of the Special Representative of the Secretary-General for Children and Armed Conflict' (UN Doc. A/HRC/37/47) (8 January)

UN SRSG for Children and Armed Conflict 2018b. 'Report of the Special Representative of the SecretaryGeneral for Children and Armed Conflict' (UN Doc. A/73/278) (30 July)

US Department of Defense 2016. 'OPAC Annex 2 - Voluntary Recruits (Accessions) of Persons Under 18', in 'US Third and Fourth Periodic Report on the Children's Protocols, Jan. 22, 2016 (revised Feb. 8, 2016)' [available at: https://www.state.gov/j/drl/rls/c70331.htm (accessed 26 November 2018)] 